\title{
IMMUNOHISTOCHEMICAL STUDY OF CADMIUM-INDUCED METALLOTHIONEIN IN THE SEMINAL VESICLE, COAGULATING GLAND, AMPULLARY GLAND AND COWPER'S GLAND OF THE RAT
}

\author{
Takanori SUZUKI*, Keiji SUZUKI**, Katsuyuki NAKajIMA***, Chikako OHMA*, \\ Masamichi HAYASHI*, Kohei KUROKAWA* and Hidetoshi YAMANAKA* \\ ${ }^{*}$ Department of Urology, ${ }^{* *}$ School of Medicine, Department of Pathology, College of Medical Care and \\ Technology, Gunma University, Maebashi, Gunma 371 and ***Japan Immunoresearch \\ Laboratories Co., Ltd., Takasaki, Gunma 370
}

Received for publication June 24, 1993 and in revised form August 5, 1993 and re-revised form September 9, 1993

\begin{abstract}
Metallothionein (MT) induction after cadmium administration in the seminal vesicle, coagulating gland, ampullary gland and Cowper's gland of the rat was immunohistochemically investigated. 1 week after castration, ten-week-old male Wistar rats were injected with testosterone propionate $(1 \mathrm{mg} / \mathrm{rat})$ once a day until the end of the experiment. After 3 weeks, rats were injected daily with a physiological saline, 0.3 $\mathrm{mg} / \mathrm{kg}$ of $\mathrm{Cd}$, and $0.9 \mathrm{mg} / \mathrm{kg}$ of $\mathrm{Cd}$. There was no significant difference between each of the four tissue weights in the three groups. MT localization was observed mainly in the basal cells of the seminal vesicle, ampullary gland and Cowper's gland, and in the epithelial cells of the coagulating gland. MT was induced by cadmium administration mainly in the basal cells of the seminal vesicle, ampullary gland and Cowper's gland, and in the epithelial cells of the coagulating gland. Immunohistochemically, differences were observed in MT induction in the cells between the coagulating gland and other three glands, and MT was thought to prevent cellular damage from toxic metals.
\end{abstract}

Metallothionein (MT) is a metal-binding protein with a low molecular weight of approximately 6,000 $\mathrm{MW}$, and high cysteine and sulfur content $(5,6)$. It is unique in its ability to bind to class II-B metals, such as zinc and cadmium, and is identified in the male genital organs $(3,8,9)$. In the rat, MT is a high content in the lateral prostate and is secreted by an apocrine type in the dorsal prostate $(8,14)$. In the human, the highest content is in the peripheral zone of the prostate, and is secreted into the prostatic fluid (9, 10). It is thought that MT is one of the secretory proteins in the prostate and plays a role in the detoxification of toxic metals $(10,15)$. The role of MT in the male accessory gland except the prostate gland is unclear, and the present study demonstrated that MT was localized in the seminal vesicle, coagulating gland, ampullary gland and Cowper's gland and is induced

Correspondence to: Dr. Takanori Suzuki, Department of Urology, School of Medicine, Gunma University, 3-39-22 Showa-machi, Maebashi 371, Japan. by cadmium administration.

\section{MATERIALS AND METHODS}

Eighteen 10-week-old male Wistar rats (Imai Experimental Animals, Saitama, Japan) were used. They were divided into three groups of six rats each and were housed in steel cages with a 12-hr-12-hr light-dark cycle. Food without cadmium (Oriental B; Oriental Yeast Co., Ltd., Tokyo, Japan) and water were given them ad libitum until the end of the experiment. This experimental protocol was performed in our Institute of Experimental Animal Research and all animals were cared for according to the "Guide for the Care and Use of Laboratory Animals" of our institute. Experimental design

All rats were castrated at the beginning of this experiment. After one week, all rats were injected subcutaneously with $1 \mathrm{mg} /$ rat of testosterone propionate (TP) (Sigma Chemical Co., St. Louis, MO) once a day until the end of the experiment. After three 
weeks, rats of group 1 were injected subcutaneously with $0.5 \mathrm{ml}$ of physiological saline as the control, group 2 with $0.5 \mathrm{ml}$ of cadmium chloride solution (Cd $\mathrm{Cl}_{2}$ ) (Cd $0.3 \mathrm{mg} / \mathrm{kg}$ ) (Kanto Chemical Co., Inc., Tokyo, Japan), and group 3 with $0.5 \mathrm{ml}$ of $\mathrm{CdCl}_{2}(\mathrm{Cd}$ $0.9 \mathrm{mg} / \mathrm{kg}$ ) once a day for six days. All animals were sacrificed under ether anesthesia. The seminal vesicles, coagulating glands, ampullary glands and Cowper's glands were immediately removed and their weights determined. The tissue weight of the seminal vesicles contained that of fluids. All specimens were fixed in $20 \%$ buffered formalin for $24 \mathrm{hr}$ and embedded in paraffin.

\section{Preparation of anti-rat $M T-1$ antibody}

MT antigen was prepared by first isolating MT-1 from the liver of Cd-treated rats, which is a kind gift from Dr. C. Tohyama (13). Next, purified MT-1 and Ascaris antigen extract were dissolved in $0.1 \mathrm{M}$ phosphate buffer $(\mathrm{pH} 7.0)$ to which $14 \%$ glutaraldehyde solution was added. Male New Zealand rabbits were immunized with the conjugate MT-1 solution, and anti-rat MT-1 antibody was obtained from their serum. This antibody is polyclonal and cross-reacts with rat MT-1 and MT-2 antigens (7).

\section{Immunohistochemical studies}

Sections were cut at a thickness of $3 \mu \mathrm{m}$ and mounted on poly-L-lysine coated glass slides. Staining was performed by means of an avidin-biotin peroxidase complex method reported previously elsewhere $(9,11,12)$. Described briefly, primary antibody $(1: 200$ dilution) was applied for $2 \mathrm{hr}$ and the secondary antibody (biotinylated anti-rabbit goat IgG) for $1 \mathrm{hr}$ at room temperature. Sections were treated with $A B C$ complex for $30 \mathrm{~min}$ and submerged in $0.05 \%$ diaminobenzidine tetrahydrochloride in $0.05 \mathrm{M}$ Trisbuffer ( $\mathrm{pH} 7.6$ ), to which $\mathrm{H}_{2} \mathrm{O}_{2}(0.01 \%)$ had been added just before use. These agents were prepared with a Vectastain ABC Kit (Vector laboratories, Inc., Burl- ingame, CA). Counterstaining was performed with Mayer's hematoxylin. The specificity of staining reaction. for MT was confirmed in a prior absorption of MT antibody with pure rabbit liver MT antigen (MT1 and/or MT-2; Sigma Chemical Co., St. Louis, MO) and omission of primary antibody from the procedure.

Statistical analysis was performed by means of the Student $\mathrm{t}$-test, and differences were considered to be significant at $\mathrm{p}<0.05$.

\section{RESULTS}

\section{Tissue weights}

Body weights (mean \pm S. D.) of rats at the end of the experiment were $389.7 \pm 23.9 \mathrm{~g}$ in group 1 , $371.3 \pm 27.6 \mathrm{~g}$ in group 2 , and $391.3 \pm 27.6 \mathrm{~g}$ in group 3. There was no significant difference between the three groups. The weights of the seminal vesicle $(\mathrm{mg} /$ $100 \mathrm{~g}$ rat) were $468.0 \pm 62.7$ in group $1,514.0 \pm 65.6$ in group 2, and $446.3 \pm 119.1$ in group 3 . The weights of the coagulating gland were $69.8 \pm 13.5$ in group $1,76.1 \pm 7.8$ in group 2 , and $74.9 \pm 8.1$ in group 3 . The weights of the ampullary gland were $22.4 \pm 5.1$ in group $1,21.5 \pm 3.2$ in group 2, and $19.3 \pm 2.5$ in group 3 . The weights of Cowper's gland were $13.5 \pm 1.9$ in group $1,12.3 \pm 2.4$ in group 2 , and $14.1 \pm 3.1$ in group 3 . There was no significant difference in each gland between the three groups. Immunohistochemical findings

There was no positive immunoreaction for MT in sections treated with preabsorbed primary antibody by pure rabbit liver MT-1 or MT-2 antigen, or with PBS in any gland of the three groups (data not shown).

Seminal vesicle (Fig. 1). Basal cells had a positive immunoreaction for MT in group 1 without cadmium administration. The localization of MT was mainly in the cytoplasm and partly in the nucleus. Epithelial cells in a part of seminal vesicles exhibited a positive immunoreaction. No reaction

TABLE 1. Summary of immunoreactivity for $M T$ in the seminal vesicle, coagulating gland, ampullary gland, and Cowper's gland

\begin{tabular}{|c|c|c|c|c|c|c|c|c|}
\hline \multirow[t]{2}{*}{ Group $^{a}$} & \multicolumn{2}{|c|}{$\begin{array}{c}\text { Seminal } \\
\text { vesicle }\end{array}$} & \multicolumn{2}{|c|}{$\begin{array}{c}\text { Coagulating } \\
\text { gland }\end{array}$} & \multicolumn{2}{|c|}{$\begin{array}{l}\text { Ampullary } \\
\text { gland }\end{array}$} & \multicolumn{2}{|c|}{$\begin{array}{c}\text { Cowper's } \\
\text { gland }\end{array}$} \\
\hline & EC & BC & EC & BC & EC & $\mathrm{BC}$ & EC & $\mathrm{BC}$ \\
\hline 1 & $-1+$ & + & $+1-$ & $+1-$ & - & + & - & - \\
\hline 2 & - & $H$ & $H$ & $H$ & - & $H$ & - & $-1+$ \\
\hline 3 & - & H & $H$ & H & - & m & $-1+$ & $H$ \\
\hline
\end{tabular}

a Group 1 as the control was injected subcutaneously with saline, group 2 was injected with $\mathrm{CdCl}_{2}(0.3 \mathrm{mg} / \mathrm{kg})$ for 6 days, and group 3 with $\mathrm{CdCl}_{2}(0.9 \mathrm{mg} / \mathrm{kg})$ for 6 days. $\mathrm{EC}$ : epithelial cells, BC: basal cells. 


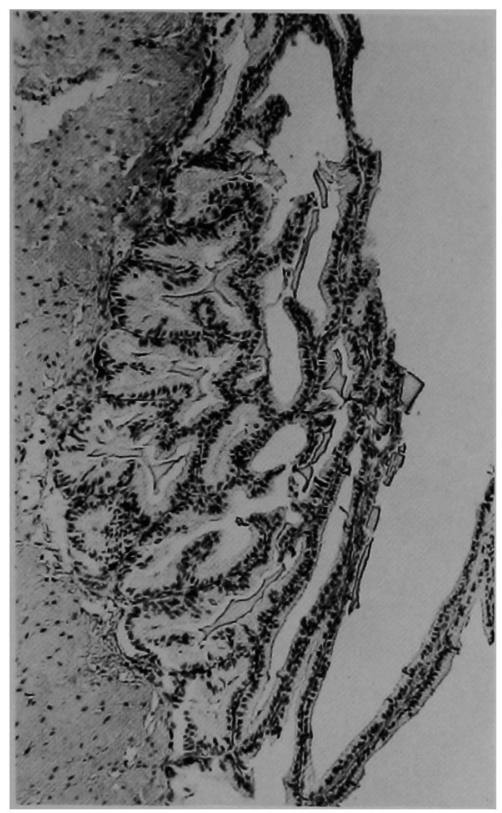

a

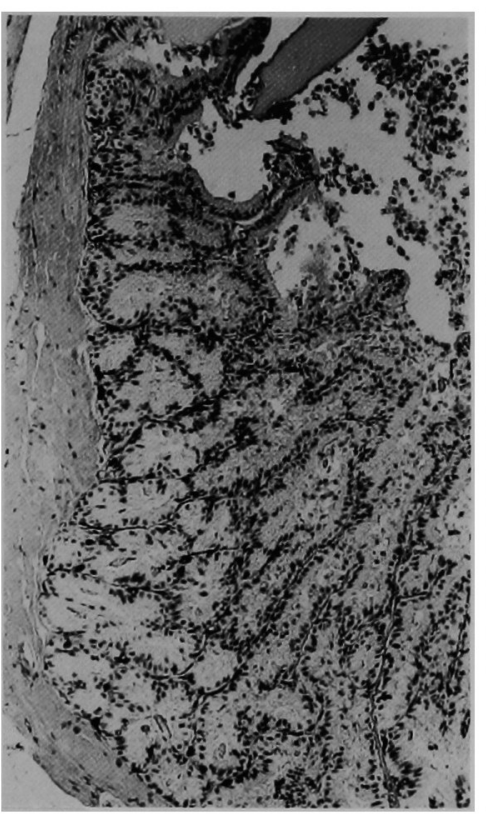

b

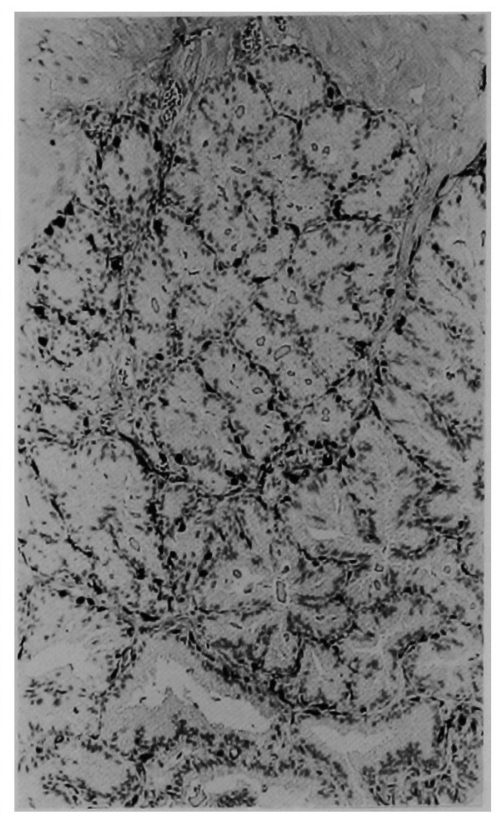

c

FIgs. 1a-c. Microphotograph of the seminal vesicle. a. A control group (group 1), b. $0.3 \mathrm{mg} / \mathrm{kg} \mathrm{CdCl} 2$ administration (group 2), c. $0.9 \mathrm{mg} / \mathrm{kg} \mathrm{CdCl} 2$ administration (group 3). MT immunoreaction was localized in the basal cells (a) and MT was induced in the same cells $(\mathrm{b}, \mathrm{c}) . \quad \times 140$

was found in the connective tissue or smooth muscle cells. In groups 2 and 3, many basal cells showed a stronger positive immunoreaction in comparison with group 1. Immunoreactivity for $\mathrm{MT}$ in the basal cells was strong in relation to the dose of $\mathbf{C d C l}_{2}$ (Table 1). There was no positive immunoreaction in any epithelial or stromal cell in groups 2 and 3.

Coagulating gland (Fig. 2). Some epithelial and basal cells exhibited a positive immunoreaction for MT, but no immunoreaction was observed in the connective tissue. The localization of $M T$ in the epithelial cells was mainly in the cytoplasm. Secretory products in the lumen had no immunoreaction in this study. In groups 2 and 3, epithelial cells showed stronger positive immunoreaction than in group 1. There was no significant change in the distribution or the intensity of MT immunostaining in the epithelial cells in groups 2 and 3 . In group 3 , most of basal cells also had a strong positive immunoreaction for MT, and immunoreactivity was strong in relation to the dose of $\mathrm{CdCl}_{2}$ (Table 1).

Ampullary gland (Fig. 3, Table 1). In group 1, basal cells had a positive immunoreaction for MT, but no immunoreaction was observed in the epithelial cells or connective tissue. In groups 2 and 3 , many basal cells had a positive immunoreaction and the intensity of MT immunostaining was stronger than in group 1. Endothelial cells in a small vessel had a positive immunoreaction in group 3, but there was no immunoreaction in the connective tissue in group 2 or 3 .

Cowper's gland (Fig. 4, Table 1). In group 1, no positive immunoreaction for MT was observed in the epithelial cells, basal cells or connective tissue. In group 2, basal cells had a weak immunoreaction, but the epithelial cells and connective tissue had no immunoreaction. In group 3, many basal cells had a strong positive immunoreaction as did a few epithelial cells. There was no immunoreaction in the connective tissue.

\section{DISCUSSION}

The testis is known to be damaged by cadmium administration of a single dose $(1.3$ to $2.6 \mathrm{mg} / \mathrm{kg})(4)$ Cadmium causes primary circulatory failure in the testis resulting in secondary destruction of the tubules and the interstitium, therefore, it damages Leydig cells producing androgens. Also, male sex accessory organs are controlled by androgens mainly derived from the testis. MT inductions in male accessory organs were performed by cadmium administration without castration $(2,14)$. But these experimental 


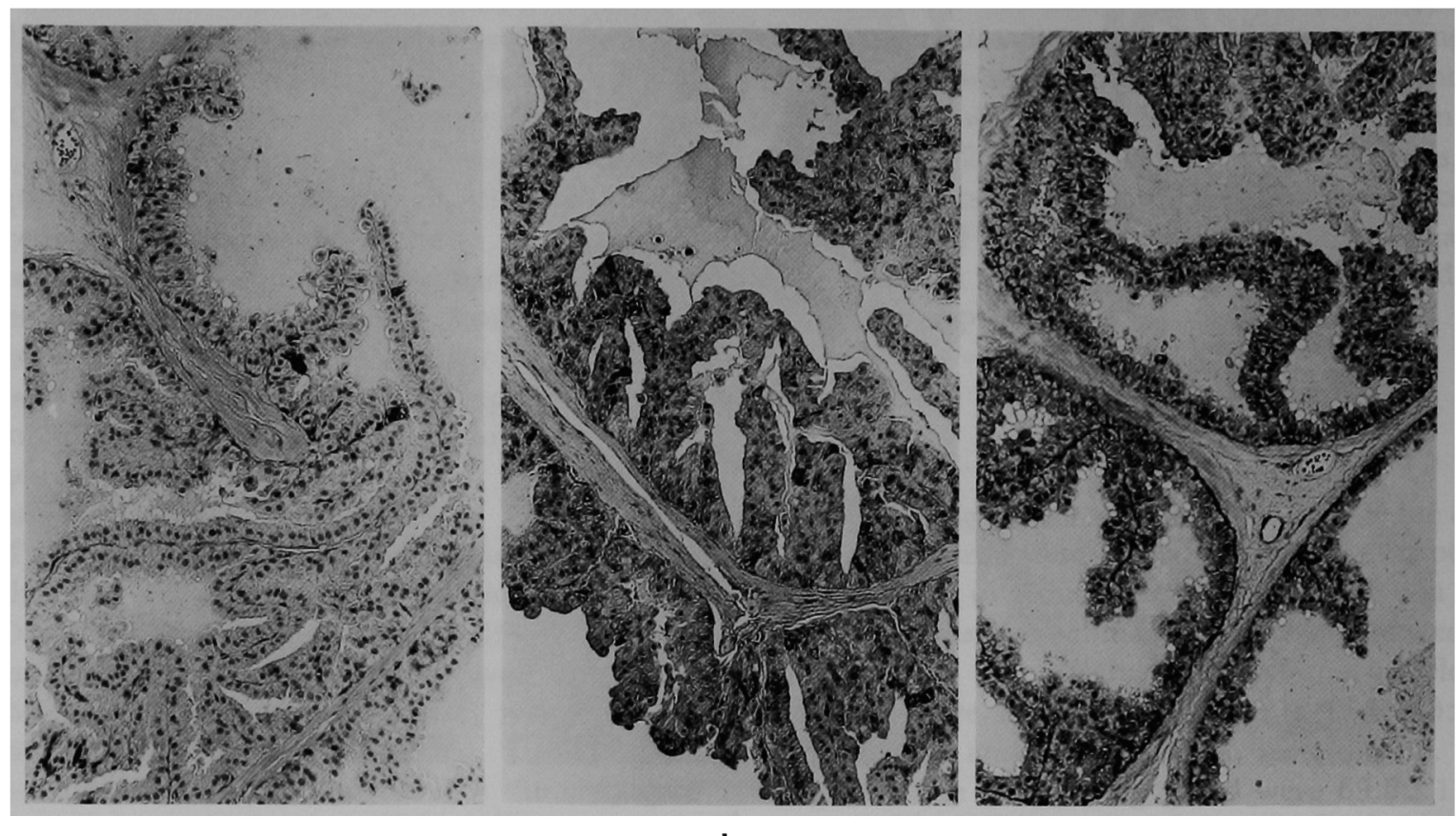

a

b

c

Figs. 2a-c. Microphotograph of the coagulating gland. a. A control group (group 1), b. $0.3 \mathrm{mg} / \mathrm{kg} \mathrm{CdCl} \mathrm{Cdministration}_{2}$ (group 2), c. $0.9 \mathrm{mg} / \mathrm{kg} \mathrm{CdCl}{ }_{2}$ administration (group 3). Immunoreaction for $\mathrm{MT}$ was localized in the epithelial cells (a) and MT was induced mainly in the same cells and partly in the basal cells $(b, c) . \quad \times 140$

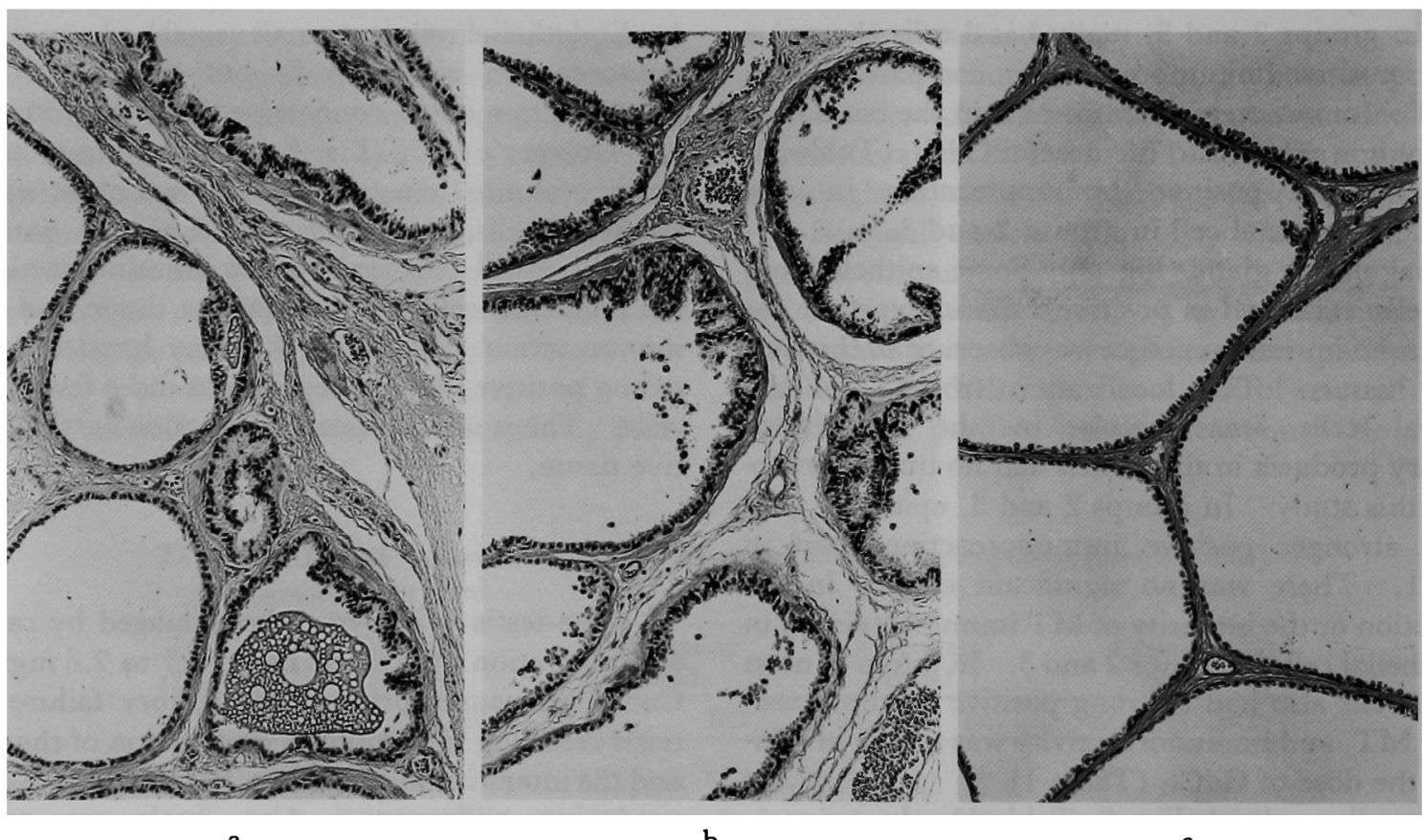

b

$\mathbf{C}$

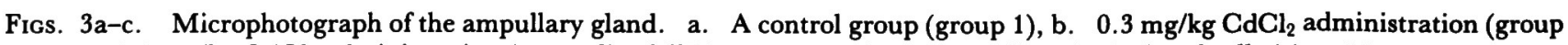
2), c. $0.9 \mathrm{mg} / \mathrm{kg} \mathrm{CdCl} 2$ administration (group 3). MT immunoreaction was localized in the basal cells (a) and MT was induced in the same cells $(b, c)$ and endothelial cells of a vessel (c). 


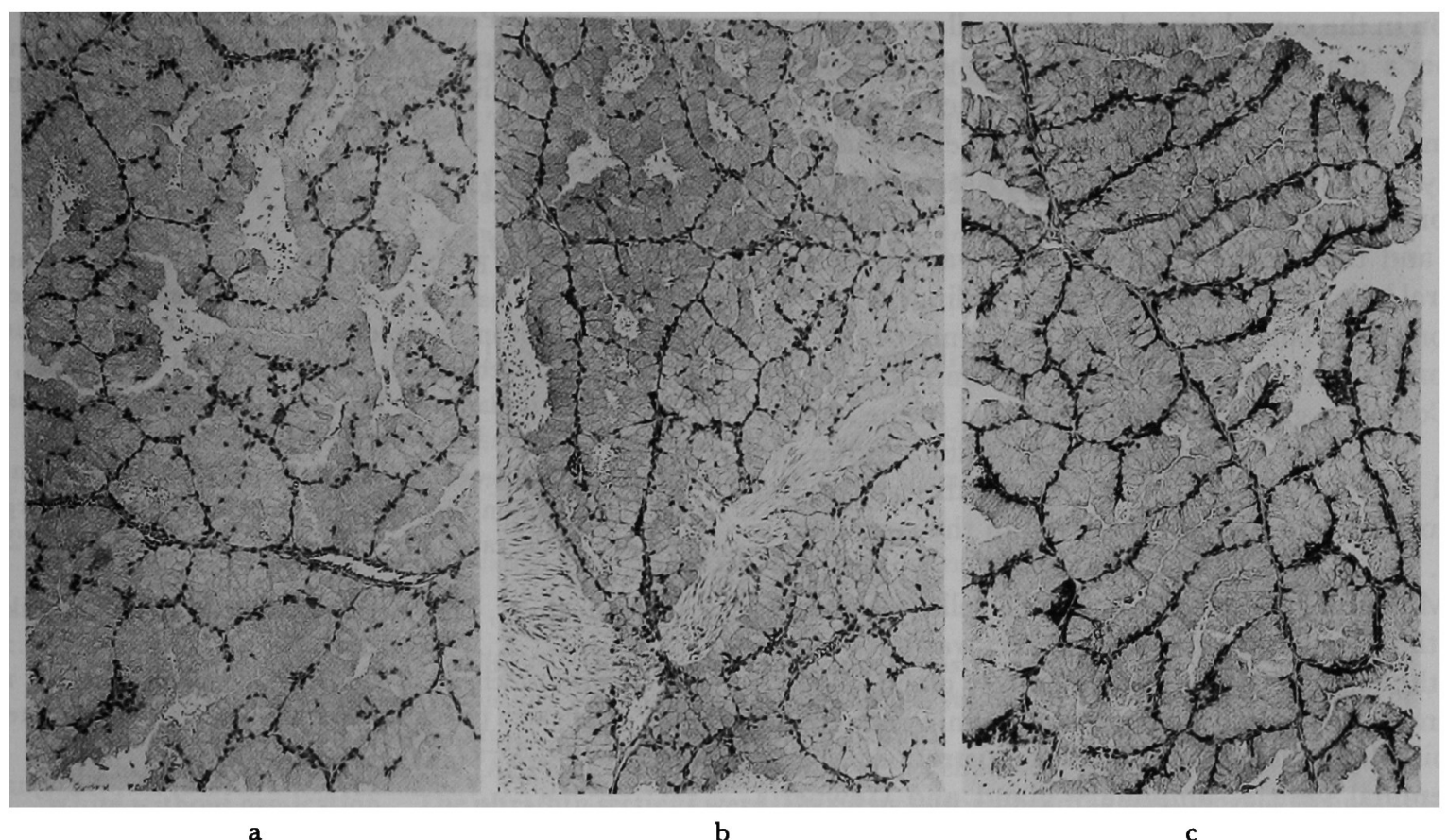

Figs. 4a-c. Microphotograph of the Cowper's gland. a. A control group (group 1), b. $0.3 \mathrm{mg} / \mathrm{kg} \mathrm{CdCl} 2$ administration (group 2), c. $0.9 \mathrm{mg} / \mathrm{kg} \mathrm{CdCl}$ administration (group 3). Immunoreaction for MT was not observed in the epithelial cells and connective tissue. MT was strongly induced in the basal cells by $0.9 \mathrm{mg} / \mathrm{kg} \mathrm{CdCl}_{2}$ administration (c).

procedures may change the level of serum androgen in animals. In this experiment, it was designed as described above that the androgen level is constant during the experiment and the function of the accessory organs is preserved. The present study demonstrated that the tissue weights of each organ were not significantly different between the three groups.

In this experiment, MT was induced in the basal cells and/or epithelial cells of the seminal vesicle, coagulating gland, ampullary gland Cowper's gland by subcutaneous $\mathrm{CdCl}_{2}$ administration. $\mathrm{MT}$ is induced by many factors including administration of zinc and cadmium, and the function of MT is thought to be the storage and transportation of essential metals, and a detoxification of harmful metals. It is identified in the male genital organs. MT is localized in the spermatogenic cells in the seminiferous tubules and high levels of MT mRNA are found in the primary spermatocytes and spermatids. MT is thought to play a role in the process of spermatogenesis (3). MT in the rat prostate shows a high content and is secreted into the prostatic fluid from the epithelial cells (14). The same finding is observed in the human prostate, and MT is thought to be one of the secretory proteins in the prostate (9). MT in the rat prostate is also induced by cadmium administration, and this data suggests that MT prevents cellular damage from harmful metals (12). But the function of MT in the seminal vesicle, coagulating gland, ampullary gland and Cowper's gland is unclear.

MT in the seminal vesicle of the rat is reported to be localized in the basal cells (8) and the finding was similar in this study. A few epithelial cells in the seminal vesicle had a positive immunoreaction for MT, while MT in the seminal vesicle of the human was localized mainly in the epithelial cells and secreted into the fluid (11). The localization of MT was different between the rat and the human. After cadmium administration, MT was induced mainly in the basal cells, and MT induction was related to the dose of cadmium administration. Aumüller et al. (1) suggested that the basal cells in the seminal vesicle play the role of nurse cells and supply zinc ions to the epithelial cells. Data in this experiment suggested that MT in the basal cells may prevent cellular damage from harmful metals. Because each tissue weight in the group of highest dose administration was not different from that of the other group, the hypothesis was also thought to be supported.

MT in the coagulating gland was reported to be localized in the epithelial cells (8) and this study showed a similar finding. There was no report of MT in- 
duction in the coagulating gland, ampullary gland and Cowper's gland. MT induction in the coagulating gland was observed mainly in the epithelial cells, and that in the ampullary gland and Cowper's gland was mainly in the basal cells. In the rat prostate, MT induction in the basal cells was observed in the ventral lobe, and that in the epithelial cells was in the dorsolateral lobe (12). The histological findings of MT induction in the coagulating gland was similar to that in the dorsolateral lobe, and that in the ampullary gland and Cowper's gland was similar to that in the ventral lobe. MT was secreted into the prostatic fluid in the dorsal prostate $(12,14)$; however, in this study, the secretory finding was not observed in the coagulating gland.

MT localization in the epithelial cells was observed in the coagulating gland, however, was not observed in the seminal vesicle and ampullary gland. While MT in the coagulating gland was mainly induced in the epithelial cells by cadmium administration, MT in the seminal vesicle, ampullary gland and Cowper's gland was induced in the basal cells. From the present study, MT is thought to have a different physiological function in each male genital organ.

\section{REFERENCES}

1. Aumüller, G., Giers, K., Giers, U., Volkl, A. and Seitz, J.: $p$-Chlorophenylalamine-induced proliferation of the seminal vesicle epithelium. Cell Tissue Res. 219; 159172, 1981.

2. Bataineh, Z. M., Heidger, P. M., Thompson, S. A. and Timms, B. G.: Immunocytochemical localization of metallothionein in the rat prostate gland. Prostate 9; 397$410,1086$.

3. De, S. K., Enders, G. C. and Andrews, G. K.: High levels of metallothionein messenger RNAs in male germ cells of adults mouse. Mol. Endocrinol. 15; 628-636, 1991.

4. Gunn, S. A. and Gould T. C.: Cadmium and other mineral elements. In "The Testis", ed. by A. D. Johnson, W. R. Gomes and N. L. Vandemark,
Academic Press, New York, 1970, pp. 377-481.

5. Kägi, J. H. R. and Vallee, B. L.: Metallothionein: a cadmium-and zinc-containing protein from equine renal cortex. J. Biol. Chem. 235; 3460-3465, 1960.

6. Margoshes, M. and Vallee, B. L.: A cadmium protein from equine kidney cortex. J. Am. Chem. Soc. 799; 4813-4814, 1957.

7. Nakajima, K., Suzuki, K., Otaki, N. and Kimura, M. Epitope mapping of metallothionein antibodies. In "Methods in Enzymology, vol. 205, Metallobiochemistry Part B, Metallothionein and Related Molecules", ed. by J. F. Riordan and B. L. Vallee, Academic Press, Inc., San Diego, 1991, pp. 174-189.

8. Nishimura, H., Nishimura, N. and Tohyama, C.: Localization of metallothionein in the genital organs of the male rat. J. Histochem. Cytochem. 38; 927-933, 1990.

9. Suzuki, T., Umeyama, T., Ohma, C., Yamanaka, H., Suzuki, K., Nakajima, K. and Kimura, M.: Immunohistochemical study of metallothionein in normal and benign prostatic hyperplasia of human prostate. Prostate 19; 35-42, 1991.

10. Suzuki, T., Yamanaka, H., Tamura, M., Nakajima, K., Kanatani, K., Kimura, M. and Otaki, N.: Metallothionein of prostatic tissues and fluids in rats and humans. Tohoku J. Exp. Med. 166; 251-257, 1992.

11. Suzuki, T., Yamanaka, H., Nakajima, K., Suzuki, K., Kanatani, K., Kimura, M., Ohma, C. and Otaki, N.: Immunohistochemical study of metallothionein in human seminal vesicles. Tohoku J. Exp. Med. 167; 127-134, 1992.

12. Suzuki, T., Yamanaka, H., Nakajima, K., Kanatani, K., Suzuki, K., Kimura, M., Nakazawa, Y. and Otaki, $\mathrm{N}$.: Induction of metallothionein by $\mathrm{CdCl}_{2}$ administration in rat prostate. Prostate 22; 163-170, 1993.

13. Tohyama, C. and Shaikh, Z. A.: Metallothionein in plasma and urine of cadmium exposed rat determined by a single-antibody radioimmunoassay. Fundam. Appl. Toxicol. 1; 1-7, 1981.

14. Umeyama, T., Saruki, K., Imai, K., Yamanaka, H., Suzuki, K., Ikei, N., Kodaira, T., Nakajima, K., Saitoh, H. and Kimura, M.: Immunohistochemical demonstration of metallothionein in the rat prostate. Prostate 10; 257-264, 1987.

15. Waalkes, M. P., Donovan, M. P. and Thomas, J. A.: Cadmium-induced prostate metallothionein in the rabbit. Prostate 3; 23-25, 1982. 